\title{
Stability in Bank Income through Fee-based Activities
}

\author{
R. K. Uppal \\ Director, ICCSR Sponsored Major Research Project \\ D. A. V. College, Malout (Punjab), India \\ rkuppal_mlt@yahoo.com
}

\begin{abstract}
This paper is an attempt to study the trends in non-interest income which is a vital source of stability in bank income. For this, the study takes some parameters like interest and non-interest income as a percentage to total income, share of non-interest income components like exchange \& brokerage, sale in investment and exchange transaction. On the basis of these parameters the study concludes that interest income is continuously declining due to deregulation in interest rates and non-interest income is rising. Among the non-interest income components, commodity exchange \& brokerage witnessed a large share while exchange transaction witnessed a meager part. The paper also gives some ways and means to bring stability in the total income.
\end{abstract}

Keywords: Trends in interest and non-interest income, components of non-interest Income, ways and means to enhance non-interest income

\section{Introduction}

After the implementation of reforms, the banking sector started to give desired results in their performance. Banking was perhaps one sector that was more deeply touched by the process of liberalization, globalization and privatization accompanying with technology advancements. Result of these reforms like liberalization, deregulation of interest rates and free entry of private and foreign banks have made the banking sector more competitive in the domestic as well as world market. To meet this competition banking sector was required to be re-oriented to be tune with the international norms and practices. In order to meet the challenges of global competition, banks have started to restructure their business. The banking sectors reforms especially deregulation of interest rates have totally changed the income structure of the banking sector. The banks have started to enter in the financial market with almost daily innovative products/services to capture maximum market share and then earn maximum profits. The banks have started to diversify their bank activities into fee-based activities that earn fee rather interest. The banks are giving considerable attention to non-interest income due to the following reasons:

(i) As interest is by far the most important cost as also income of banks, but due to the deregulation of interest rates, now rates are decided by market forces, which resulted in continuous decrease in interest rates due to the cut-throat competition in the financial market. Due to this trend of falling rate of interest, interest income of the banks is continuously deteriorating day by day, resulting in lower profitability. To offset this reduction in interest income, banks have started to emphasis more on fee-based activities.

(ii) Continuous increase in income from sources of non-interest income, also attract the banks to go for fee-based activities.

All banks are eager to go for fee-based activities to a large extent with various sources of income. At present, the banking sector income is divided into two major parts i.e. interest income and non-interest income. The structure of income is given below:

Interest Income

Interest/Discount

Income on Investment

Balance with RBI

Others

\author{
Non-Interest Income \\ Commission \& Brokerage \\ Sale of Investment \\ Sale of Land Building \\ Exchange Transaction \\ Income from E-delivery Channels \\ Misc. Income
}


It is therefore, important to examine to what extent fee-based income contributes to total income. These days, banks are competing on the basis of fee-based activities by launching innovative products/services. Noninterest income is a vital part of total income of the banks and it may create stability in bank income. The objectives of the study are

- To study and analyze the trends in interest income and non-interest income in the era of deregulation.

- To find out the various ways and means to enhance the non-interest income.

\section{Review of Literature}

Aggeler and Feldman (1998) found in their study that while net interest income of the banks rose by $12 \mathrm{pc}$ over the period of 1992-97, the bigger in bank earnings came from non-interest income. Non-interest income grew by $34 \mathrm{pc}$ in this period-nearly three times fast as interest income. Davis (2002) studied the changing structure of the European Banks. They found that EU banks have not been able to increase their non-interest income sufficient to offset falling interest income and given some suggestions to improve it. They concluded that relation of non-interest income to profitability tends to be positive.

Mahadevan (2002) describes some major changes in the banks business occurring during the financial reforms period, affecting the profitability. He has given wide variety of strategies to increase non-interest income. Nash (1993) found that credit Card lending specialization gives higher and more volatile returns than achieved by banks with conventional product mixes. Rosie \& Wood (2002) studied in their working paper the income structure of European Banking Sector with the help of time series and cross-sectional analysis. They concluded that non-interest income has increased but does not fully offset the reduction in the interest margin and non-interest income is much more volatile than interest income.

Walters (1994) in his study found that the expansion of banks' activities reduces risk, with the main risk reduction gains arising from insurance rather than securities activities. Young and Roland (1999) in their paper correlating product mix with earnings at commercial banks, consider three fundamental observations each of which shows that fee-based income need not be more stable than income from traditional banking activities.

\section{Research Methodology and Database}

\subsection{Research Design}

In the last few years, interest rates have been deregulated. However interest rates have begun to come down. As a consequence of this low interest rate income of the banks has reduced. Thus banks have find out the ways to increase their other income. The present paper is mainly concerned with non-interest income of the banks.

\subsection{Sample Design}

The universe of the study is Indian banking industry. Indian banking industry has been divided into four parts.

- Public Sector Bank Group - G-I (28)

- $\quad$ Old Private Sector Bank Group - G-II (20)

- New Private Sector Bank Group - G-III (08)

- Foreign Bank Group - G-IV (29)

\subsection{Parameters of Study}

- Share of commodities exchange and brokerage in other income.

- Share of sales in investment in other income.

- Share of exchange transaction in other income.

- Interest income as a percentage to total income

- Non-interest income as a percentage to total income 


\subsection{Time Unit}

All the parameters have been analyzed for the period 2000 to 2008. This time period is considered for study because after the introduction of IT Act, sources of other income increased.

\subsection{Data Collection Method}

Data has been collected from Performance Highlights, Various Issues, IBA Publication, Mumbai.

\subsection{Statistical Tools}

Statistical methods like mean, standard deviation, coefficient of variance, coefficient of correlation have been used to analyze the data.

\section{Results and Discussion}

\subsection{Share of Commodities Exchange and Brokerage in Other Income}

Commodity exchange and brokerage is one of the important components of interest income. It is clear from table 1 that share of commodities exchange and brokerage is increasing in all the bank groups but in the year 2007-08 share of commodities exchange has decreased. Overall, average share of commodity exchange and brokerage in non-interest income is more in new private sector bank group i.e. $53.48 \mathrm{pc}$ and it is least in old private sector bank group i.e. $36.52 \mathrm{pc}$.

Table 1: Share of Commodities Exchange and Brokerage in Other Income

\begin{tabular}{lllll} 
& & \multicolumn{3}{c}{ Per cent } \\
\hline Year & G-I & G-II & G-III & G-IV \\
\hline $2000-01$ & 53.14 & 47.40 & 51.77 & 51.06 \\
$2001-02$ & 41.21 & 21.86 & 31.60 & 38.92 \\
$2002-03$ & 34.28 & 21.64 & 32.01 & 45.00 \\
$2003-04$ & 27.78 & 21.73 & 46.80 & 42.56 \\
$2004-05$ & 37.56 & 44.69 & 60.49 & 55.40 \\
$2005-06$ & 43.40 & 45.80 & 64.99 & 49.82 \\
$2006-07$ & 59.9 & 49.93 & 74.38 & 54.62 \\
$2007-08$ & 46.99 & 39.15 & 65.83 & 50.87 \\
Mean & 43.03 & 36.52 & 53.48 & 48.53 \\
S.D & 10.31 & 12.60 & 15.84 & 5.83 \\
C.V (\%) & 23.96 & 34.50 & 29.61 & 12.01 \\
\hline
\end{tabular}

Source: Performance Highlights, Various Issues, IBA Publication, Mumbai

\subsection{Share of Sale in Investment in Other Income}

Sale in investment is another component of non-interest income. From the year 2000 to 2004 this component shows an increasing share but after this year share of this component has decreased. In case of foreign bank group it becomes negative. But in the year 2008 this component shows improvement. Large variations are found in foreign bank group while least in public sector bank group.

\section{Table 2: Share of Sale in Investment in Other Income}

\begin{tabular}{lllll} 
& & \multicolumn{3}{c}{ Per cent } \\
\hline Year & G-I & G-II & G-III & G-IV \\
\hline $2000-01$ & 18.18 & 16.71 & 20.02 & 13.77 \\
$2001-02$ & 36.30 & 62.57 & 54.16 & 31.43 \\
$2002-03$ & 46.65 & 62.08 & 31.27 & 16.40 \\
$2003-04$ & 54.82 & 59.76 & 39.36 & 15.93 \\
$2004-05$ & 35.27 & 15.71 & 9.97 & -14.90 \\
$2005-06$ & 19.05 & 14.95 & 12.46 & -11.65 \\
$2006-07$ & 14.21 & 17.30 & 12.13 & -13.21 \\
$2007-08$ & 25.32 & 18.25 & 16.72 & 1.39 \\
Mean & 31.22 & 33.41 & 24.51 & 4.89 \\
S.D & 14.53 & 23.26 & 15.74 & 17.08 \\
C.V (\%) & 46.54 & 69.61 & 64.21 & 349.28 \\
\hline
\end{tabular}

Source: Performance Highlights, Various Issues, IBA Publication, Mumbai 


\subsection{Share of Exchange Transaction in Other Income}

Share of exchange transaction is given in table 3. Table indicates that exchange transaction component witnessed a small share in non-interest income in all the bank groups except foreign bank group. But in spite of small share this component shows an increasing trend.

Table 3: Share of Exchange Transaction in Other Income

\begin{tabular}{lllll} 
& & \multicolumn{3}{c}{ Per cent } \\
\hline Year & G-I & G-II & G-III & G-IV \\
\hline $2000-01$ & 11.03 & 9.42 & 12.58 & 27.95 \\
$2001-02$ & 9.35 & 5.10 & 6.60 & 20.52 \\
$2002-03$ & 7.86 & 5.22 & 3.16 & 28.91 \\
$2003-04$ & 6.70 & 5.06 & 7.35 & 35.69 \\
$2004-05$ & 9.12 & 11.88 & 9.81 & 42.46 \\
$2005-06$ & 10.88 & 9.17 & 10.15 & 39.18 \\
$2006-07$ & 10.58 & 8.50 & 11.20 & 39.83 \\
$2007-08$ & 9.29 & 9.37 & 4.82 & 36.01 \\
Mean & 9.35 & 7.96 & 8.20 & 33.81 \\
S.D & 1.51 & 2.54 & 3.26 & 7.39 \\
C.V (\%) & 16.14 & 31.90 & 39.75 & 21.85 \\
\hline
\end{tabular}

Source: Performance Highlights, Various Issues, IBA Publication, Mumbai

\subsection{Non-interest Income as a percentage of Total Income}

Non-interest income of all the bank groups is increasing as given in table 4. Average non-interest income is more in foreign bank group as compared to other bank groups because this group is providing many feebased services. Fluctuations are more in old private bank group and least in foreign bank group.

Table 4: Non-interest Income as a percentage of Total Income

\begin{tabular}{lllll} 
& & \multicolumn{3}{c}{ Per cent } \\
\hline Year & G-I & G-II & G-III & G-IV \\
\hline $2000-01$ & 11.95 & 11.35 & 14.14 & 20.96 \\
$2001-02$ & 14.09 & 20.28 & 20.74 & 25.15 \\
$2002-03$ & 16.55 & 20.83 & 21.65 & 25.50 \\
$2003-04$ & 20.42 & 21.00 & 24.06 & 29.89 \\
$2004-05$ & 16.62 & 12.54 & 23.11 & 29.64 \\
$2005-06$ & 14.49 & 12.07 & 24.16 & 29.82 \\
$2006-07$ & 11.04 & 11.42 & 19.66 & 27.79 \\
$2007-08$ & 12.97 & 12.52 & 20.73 & 30.13 \\
Mean & 14.76 & 15.25 & 21.03 & 27.36 \\
S.D & 3.02 & 4.54 & 3.23 & 3.26 \\
C.V (\%) & 20.46 & 29.77 & 15.35 & 11.91 \\
\hline
\end{tabular}

Source: Performance Highlights, Various Issues, IBA Publication, Mumbai

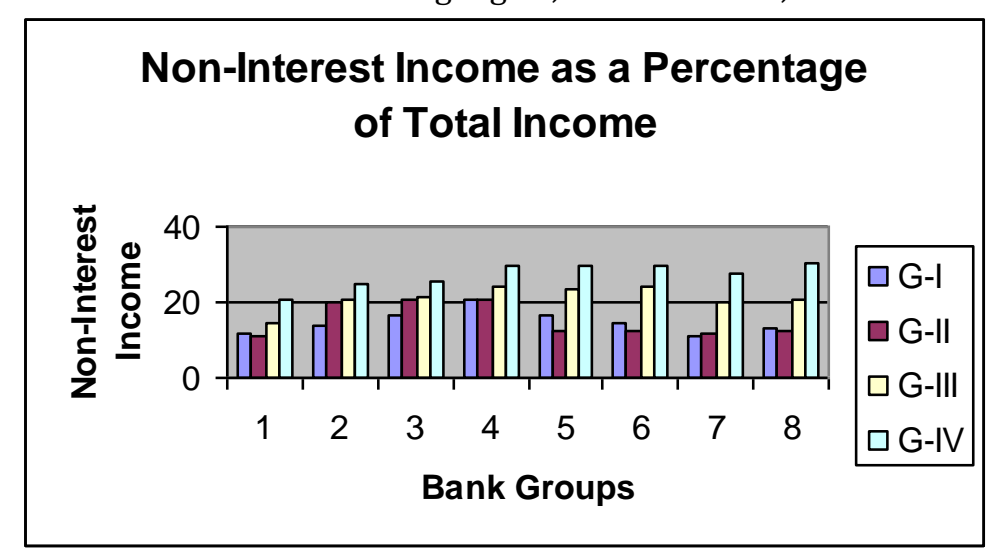




\subsection{Interest Income as a Percentage of Total Income}

Trends in interest income shows in table 5 clears that interest income of the bank groups is decreasing. The major reason for this decrease in interest income is deregulation of interest rate. Overall, interest income is more in public and old private sector bank group while least in foreign bank group because this group is focusing on non-interest income rather than interest income.

Table 5: Interest Income as a Percentage of Total Income

\begin{tabular}{lllll} 
& & \multicolumn{3}{c}{ Per cent } \\
\hline Year & G-I & G-II & G-III & G-IV \\
\hline $2000-01$ & 88.04 & 88.64 & 85.85 & 79.03 \\
$2001-02$ & 85.90 & 79.71 & 79.25 & 74.84 \\
$2002-03$ & 83.44 & 78.68 & 78.34 & 74.49 \\
$2003-04$ & 79.57 & 78.99 & 75.93 & 70.10 \\
$2004-05$ & 83.37 & 90.03 & 76.88 & 70.35 \\
$2005-06$ & 85.50 & 87.92 & 75.83 & 70.17 \\
$2006-07$ & 88.95 & 88.57 & 80.33 & 72.20 \\
$2007-08$ & 87.02 & 87.47 & 79.26 & 69.86 \\
Mean & 85.22 & 85.00 & 78.95 & 72.63 \\
S.D & 3.02 & 4.92 & 3.23 & 3.26 \\
C.V (\%) & 3.54 & 5.78 & 4.09 & 4.48 \\
\hline
\end{tabular}

Source: Performance Highlights, Various Issues, IBA Publication, Mumbai

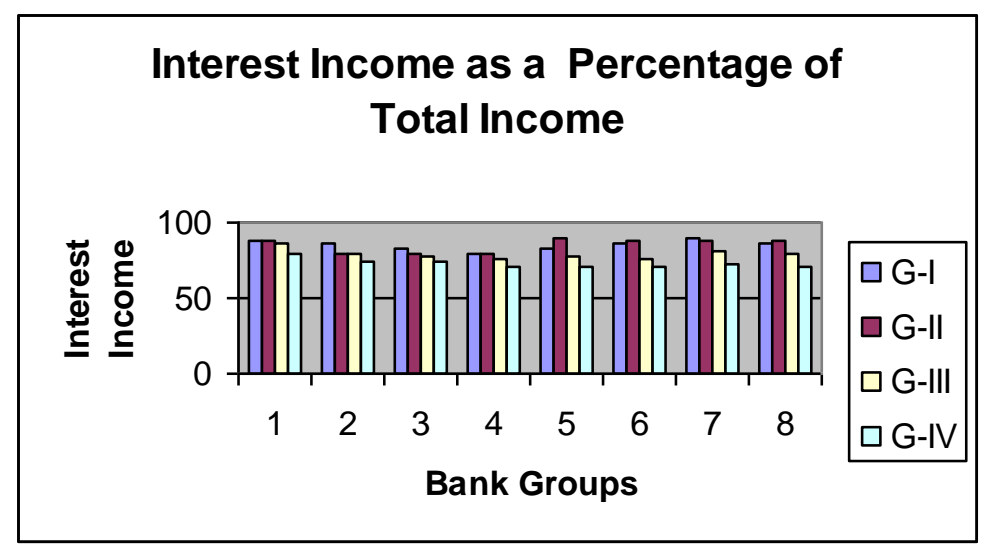

\section{Ways and Means to Enhance Non-Interest Income}

It is evident from the ongoing analysis that there is a need to enhance non-interest income and we are suggesting the following strategies to enhance non-interest income.

\subsection{Remittance of Funds}

Banks are suitable for remittance of funds from one place to another through mass instruments like mail transfer, telegraphic transfer, bank drafts, traveler's cheques, EFT etc. Customers are required to pay a small fee for utilizing these facilities that become a source of income for banks either in the form of commission or any other fee based source.

\section{Strategies for increasing remittance of business}

- Offer excellent customer service at the counter.

- Appoint tellers in heavy draft business branches for receiving cash and issuing draft. They may be authorized even to sign the drafts.

- Open branches in areas having large inflow and outflow of drafts. 
- Create links with educational institutions to accept their bank drafts for fee collection, donation etc. also with hotels, restaurants and supermarkets to motivate them to accept their traveler cheques.

- Issue and encash bank drafts electronically to save the time and to provide the accurate results.

- Extend business hours in the selected branches for issuing drafts.

- Obtain standing instructions from customers to issue mail transfers/drafts.

- Charge higher commission for issuing drafts of large amount.

- Give concession to the customers who give sizeable draft business during the year.

\subsection{Safe Custody of Valuables}

Banks, well equipped with safe and strong rooms, can accept valuables for safe custody and can earn good income.

\section{Strategies to enhance this business}

- Increase rent for lockers, will never affect their customers because the rich class mostly uses lockers and normally utility of money is less for the rich class.

- To use the locker facilities, banks should fix minimum amount required to be maintained in their saving accounts.

- Banks should advertise the availability of lockers and safe custodies.

- Banks should provide concession for the lockers and safe custody to those customers who have more deposits in their current accounts.

- Lockers can be installed at extension counters also.

- Vacant lockers to be hired out and rent to be collected within the stipulated date.

- Facility of nominations, use of lockers in the off time should be given to the customers.

\subsection{Letter of Credit and Letter of Guarantee}

Banks lend their creditworthiness to the beneficiaries by issuing LCs and LGs to get commission from the customers for these facilities. These facilities add to risk exposure, so should be extended to effective/potential parties only.

\section{Strategies to enhance this business}

- Loaning power for granting the above facilities should be enhanced at the field level. It will fulfill the needs of the borrowers and will save the time.

- Banks should offer PLR to borrowers to give the banks substantial non-fund business.

- A bank officer may be posted at commercial centers to exclusively canvass non-fund business.

- Banks should create links with intermediaries to convince/attract the potential customers to use LCs and LGs.

\subsection{Government Business}

When a bank hold government business, can get commission from the RBI. Government business may be in the form of, payment of pensions, collection of taxes. Many banks are providing such facilities and getting a substantial income from this source.

\section{Strategies to enhance this business}

- List of retiring persons should be collected from government departments/railways/defense departments and efforts made to canvass their pension. Respect the old citizens and provide some attractive facilities. Recently some state governments are providing old-age pension, banks should try to offer such facilities to get commission from such a facility.

- The efficient staff should be appointed to provide facilities of pension.

- The banks should create their links with the various departments to get income from this source. 


\subsection{Exchange Transactions}

Remuneration from exchange transaction is a major source of non-interest income for the banks. It depends upon the quantum of export profits which further depends on the export and import turnover along with the exchange rates of the currencies.

\section{Strategies to enhance this business}

- Branches should encourage the exporter/importers to book forward contracts, which give ample scope for improving this income.

- All the potential officers should be given permission for trading in currencies.

- Bank should create links with DGFT/ECGC to ascertain the list of importers/exporters in their command areas.

- Bank should give concession to the importers/exporters in issuing the drafts, LCs, LGs etc. and some other concessions.

\subsection{Issuance of stock investment}

Stock investment is the non-negotiable instrument used to subscribe capital in the primary capital market. The investor deposit the application money in it's de-mat accounts and gets interest till the allotment of shares/debentures by the company.

\section{Strategies to enhance this business}

- Banks should distribute the pamphlets to popularize the de-mat services.

- Banks should give concession in the fee charged for the de-mat services to potential customers.

- Banks should create links with the stock brokers to procure the list of investors who can directly contact the banks to sell their stock invest.

- More branches should be added to provide facilities of these services.

\subsection{Miscellaneous Non-Interest- Income}

- Services charges for credit cards should be increased at least to the bearable extent.

- Banks should collect ledger-folio charges from current account holders.

- Banks should collect processing fee for fresh/enhancement/renewal of limit.

- Banks should collect incidental charges for not maintaining minimum balance in current and saving account.

- Banks should charge nominal fee for the collection of local cheques to at least the cover the cost incurred for clearing business.

\section{Conclusion}

To conclude, competition is prevailing in the Indian economy. The non-interest income activities of banks are also on the increase in recent years. This has helped to stabilize the total income of banks. This has helped to stabilize the total income of banks. Increase in non-interest income as a source of funds for banks would also greatly be helpful for maintaining the financial soundness of banks. Interest is by far the most important cost as also income of banks. Now a days due to the introduction e delivery channels by various banks the source of other income has changed. Some new private sector banks and foreign banks are earring non interest from e delivery channels. The gap between public and private sectors banks is increasing. The public sector banks should adopt new methods to increase their non interest income. 


\section{References}

Aggeler, H and Feldman, R (1998), "Record Bank Profitability: How, Who and What Mean?" Federal Reserve Bank of Minneapolis, Fedgazette, 10(2), 10-21.

Bhatt, P.R. (1999), "Profitability of Commercial Banks in India," Indian Journal of Economics, 3(4), 202-214.

Boyd, J and Graham, S (1986), "Risk, Regulation, and Bank Holding Company Expansion of Non-Banking," Federal Reserve Bank of Minneapolis, Quarterly Review, 10(2), 2-17.

Boyd, J, Graham, S and Hewitt, R (1992), "Bank Holding Company Merger with Financial Firms: Effects on the Risk of Failure," Journal of Banking and Finance, 17, 43-63.

Davis, P.L. (2002), "The Changing Structure of Banks' Income-Empirical Investigation" Journal of Economics and Business, 2(3), 219-23.

Kaveri, V. S. (2001), "Loan Default and Profitability of Banks," IBA Bulletin, January.

Mahadevan, K (2002), "Non-Interest Income: Our Potential Strategies to Increase its Share," Edited Book, Management of Banking and Financial Institutions, Deep \& Deep Publications, New Delhi, 59-69.

Murthy, G.R.K. (2001), "Banks Foray into Insurance: The Road Ahead," IBA Bulletin, 23(10), 23-36.

Nagarajan, N. (2002), "Other Income of Banks since 1993-94," IBA Bulletin, 24(11), 6-12.

Narayanan, V. (2000), “NPA Reduction-The New Mantra of Slippage Management," IBA Bulletin, 22(10) 15-23.

Ram, T. T. (2002), "Deregulation and Performance of Public Sector Banks," EPW. 27(5), 393-408.

Rangarajan, C. (2000), "Banking in the Hi-Tech. Environment," The Journal of The Indian Institute of Bankers. (Jan-March).

Rose, S. (2003), "Non-Interest and Total income Stability," Working Paper No. 198.

Sinkey, J and Nash, R (1993), "Assessing the Riskiness and Profitability of Credit Cards," Journal of Financial Services Research, 7(2), 127-50.

Swamy, B. N. A. (2001), "New Competition, Deregulation and Emerging Changes in Indian Banking: An Analysis of the Comparative Performance of Different Bank- Groups," Bank Quest, The Journal of Indian Institute of Bankers.

Wall, L, Reichert, A and Mohanty, S (1993), "Deregulation and the Opportunities for Commercial Bank Diversification," Federal Reserve Bank of Atlanta, Economic Review, 72(3), 3-22.

Verghese, S. K (1983), "Profits and Profitability of Indian Commercial Banks in the Seventies," EPW, (Nov.), 145-157. 